\title{
WEARABLE TECHNOLOGY ADOPTION AMONG ROMANIAN STUDENTS: A STRUGTURAL MODEL BASED ON TAM
}

\author{
Mihai Felea $^{1^{*}}$, Mihaela Bucur ${ }^{2}$, Cristian Negruțiu ${ }^{3}$, Maria Niţu \\ and Dragoș Andrei Stoica ${ }^{5}$ \\ ${ }^{122) 344) 5)}$ Bucharest University of Economic Studies, Romania
}

\author{
Please cite this article as: \\ Felea, M., Bucur, M., Negruțiu, C., Nițu, M. and Stoica, \\ D.A., 2021. Wearable Technology Adoption Among \\ Romanian Students: A Structural Model Based on \\ TAM. Amfiteatru Economic, 23(57), pp.376-391.
}

\section{Article History}

Received: 23 December 2020

Revised: 10 February 2021

Accepted: 20 March 2021

DOI: $10.24818 / \mathrm{EA} / 2021 / 57 / 376$

\begin{abstract}
The Internet of Things (IoT) has gained particular attention, both from academia and from companies and industries, as a result of its characteristics and the opportunities that this technology generates for end-users and for the business environment. Thus, the creation of this network that connects the objects around us allowed optimization and improvement of activities in various fields.

The adaptation and deployment of IoT in wearable smart devices has created an important market, due to the popularity, the functionality and the use of these devices in various professional and everyday activities. The purpose of this paper was to examine the adoption of wearable technology in the broader context of the development of innovations and technologies in the field of IoT. A new theoretical model based on Technology Acceptance Model (TAM) was developed and tested to identifying the relations between factors influencing the attitude towards use and the intention to use of wearable devices. A survey carried out on Romanian students provided the necessary data to test the model. The results of Structural Equation Modelling (SEM), based on the Partial Least Squares (PLS) method, led to the acceptance of eight out of the nine issued hypotheses, indicating that the three exogenous variables (perceived usefulness, perceived enjoyment and visual attractiveness of wearable devices) have a significant positive influence (with one exception) on endogenous variables (intention to use and attitude towards the use of wearable devices).
\end{abstract}

Keywords: Wearable Devices, Internet of Things (IoT), Technology Adoption, Technology Acceptance Model (TAM), Structural Equation Modelling (SEM), Partial Least Squares (PLS)

JEL Classification: L86, O33, C12

* Corresponding author, Mihai Felea - e-mail: mihai.felea@com.ase.ro

\section{Authors' ORCID:}

Mihai Felea: orcid.org/0000-0001-9375-6912

Mihaela Bucur: orcid.org/0000-0003-0867-2971

Cristian Negruțiu: orcid.org/0000-0003-1857-8567

Maria Nițu: orcid.org/0000-0001-6314-9601

Dragoș Andrei Stoica: orcid.org/0000-0002-7846-189X 


\section{Introduction}

The Internet of Things (IoT) is a new concept that designates a connected network of people, processes, data and things that together are able to achieve more relevant and valuable results. In this context, IoT can make significant improvements in all economic and social areas, but also on a personal level (consumers, households) and a professional level (companies and other organisations). Wearable devices present a concrete application in the personal area of IoT technology, presenting a strong development in recent times.

IoT offers opportunities and challenges related to the consumer (Onete, Pleşea, and Albăstroiu, 2017) and must be placed in the broader context of innovation and progress in the area of the Internet and communications in particular. The term was first presented by Kevin Ashton in 1999 as a way to describe objects connected to the Internet. Subsequent definitions followed, including the proposal of the International Telecommunication Union (ITU), the UN specialised body in the field of information and communication technology. According to the ITU (2012, p.1), IoT is "a global infrastructure for the information society that must enable advanced services through the interconnection of things (physical and virtual) based on existing interoperable and evolving information and communication technologies".

The development of theoretical models relating to the acceptance of technology allows the efficient implementation of an information system, i.e. a technology by understanding the consumer behaviour of users. Thus, the TAM model developed in 1989 by Fred D. Davis, which examines consumers' intention to use systems/technology and actual use, represents a first step in this direction, followed by an extension of the model - TAM 2.

The aim of this paper is to analyse the adoption of wearable devices technology among Romanian students. Therefore, this article is divided into four sections. The first part includes the review of the scientific literature on IoT, wearable technology and the theories regarding accepting technology. The second section presents the proposed model and the research hypotheses, while the third part describes the research methodology. The research's results are presented in the fourth section, alongside discussions referring to the structural model.

\section{Literature review}

\subsection{Internet of Things}

Following the explosive development of practical IoT applications in recent times, there has been and continues to be increased interest from researchers for this field. Therefore, the scientific literature in the field of IoT is extensive and encompasses various research perspectives.

Concerning the historical evolution of the IoT concept, Ibarra-Esquel et al (2017) distinguish three major phases of evolution. Phase I includes the birth and first clarifications of the concept on the basis of the definitions cited above. At this stage, the concept was generally referring to connecting computers in various fields. In Phase II we are witnessing a consolidation of the concept, as well as the integration of objects, different from computers. The IoT paradigm is defined at the intersection of three visions, the semantic one, the one related to objects, and the Internet (Figure no. 1). Finally, in Phase III, we notice a clear trend 
towards the growth of the data and services area by developing diverse applications, both in the professional and domestic area.

At this stage of clarification, it is also important to define what the term of objects in the IoT concept refers to. According to Ibarra-Esquer et al (2017), these objects have the following properties: identification, localization and tracking, detection, actuation and processing. The last feature is specific to more technically advanced objects, but the first four properties are essential for defining an object in the notion of IoT. In the same note, Klein, Pacheco and Righi (2017) identify several additional elements, related to cooperation and the user interface. This last aspect is particularly relevant in the consumer application area.

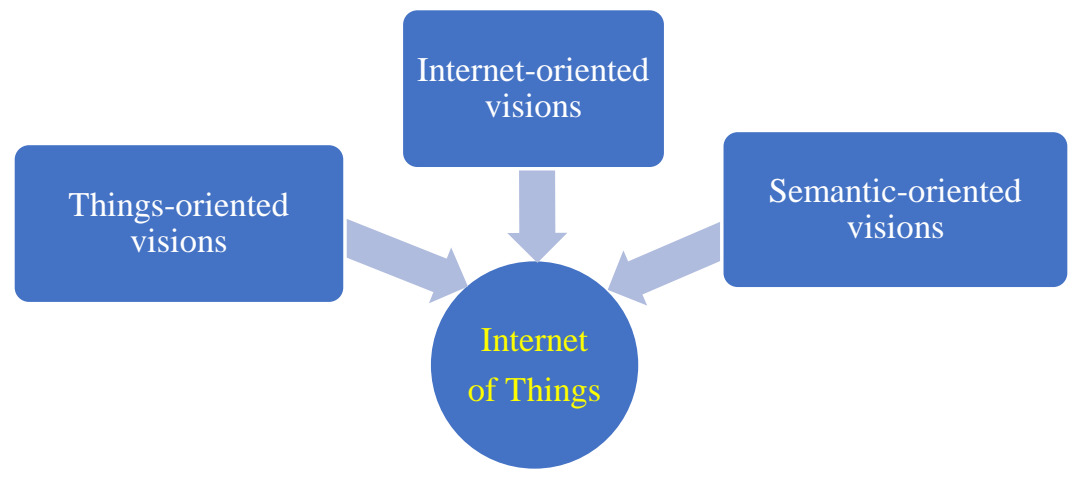

Figure no. 1. Internet of Things paradigm

Source: Ibarra-Esquer et al, 2017, p. 9

Russo et al (2015) sees the concept of IoT integrated into a broader view, comprising three main areas: the Energy Internet (IoE), the Communications Internet (IoC) and the Logistics Internet (IoL). These three areas created the global platform that now enables large-scale distribution and success of the IoT concept. In the same note, Murray et al (2016) describes the IoT concept as a specific application of the broader concept of innovation. Furthermore, the authors argue that the introduction of IoT into a company's processes brings, in addition to tangible (financial) benefits, an increase in intangible assets and intellectual capital. This last aspect is also reached by Uden and Wu (2017) in a study dedicated to the impact of IoT on knowledge management. The authors argue that due to the virtual and extensive nature of the interactions between processes and systems allowed by IoT technology, knowledge management in an organization can experience a huge leap. The authors illustrate their thesis through a case study of a smart parking system where the IoT technology has also brought a significant increase in customer satisfaction.

Internet of Things are among the new drivers of the actual economy and together with other Internet based technologies have a critical impact on organizational performance (Tohanean, Toma and Dumitru, 2018). The economic value of IoT systems is analysed in detail by Westerlund, Leminen and Rajahonka (2014). Lately, the concept of IoT has evolved from a technological platform to a business ecosystem. In this context, the researchers ask a pertinent question - can IoT-based business systems generate enough profit, are they economically viable? According to the authors, there are three important barriers to be considered: diversity of embedded objects; lack of maturity of innovation in the field and high degree of nonstructuring of business models. To overcome these difficulties, the authors propose an 
integrated approach and several essential elements in the design of an IoT-based business model. The potential to create value is also found in Jin and Ji (2018) as the term most commonly associated with research related to IoT-based business models. In a comprehensive review of literature, the authors also identify other key terms associated with IoT: the challenge (challenging) of current business models, the concept of "open source", as well as association with entrepreneurship and small companies. IoT-based business models are also approached by Klein, Pacheco and Righi (2017) using the Canvas tool, which is a holistic approach to a business, especially at the beginning of the road. The authors argue that the biggest challenges in the design of such a model are: the IoT; product/service development; value sentence; the company's internal capabilities ; technological infrastructure and revenue generation mode.

In a follow-up study, Nicolescu et al (2018) extends IoT's value concept through the economic, social and technical perspectives, adding that an integrated approach is essential for understanding the concept and assessing the benefits of IoT. From a social point of view, the authors highlight several key features related to working with human agents, ensuring the necessary digital skills, integrating multiple different social values (especially those related to the security and protection of personal data), as well as the legal framework, still underdeveloped. From an economic point of view, the authors note the lack of economic and cost-calculation models associated with IoT, as well as the associated risks and opportunities. In the field of social factors, the authors note the need for a multidisciplinary expertise in the design of IoT systems, also associated with a higher requirement of standardization and interoperability. The authors also propose a functional model of IoT systems, which takes into account the factors presented above and is very useful for differentiating between the professional area and the household area.

\subsection{Wearable devices}

Wearable devices are an important application of IoT technology, which has developed extensively over the last period. By wearable device (or wearable technology) we mean any computer device that communicates with other devices. The examples are numerous: smartwatches, smart strips, smart glasses, or even smart jewellery. Wearable devices are systems worn by individuals or attached to the clothing they wear to perform different specific functions or tasks (Khakurel, Pöysä și Porras, 2017). A large part of the gadgets/devices integrated different types of sensors that collect information and data in order to develop and improve these devices and consumer experiences. Thus, these technologies are concerned with providing direct responses to consumers, such as minimum energy consumption, seamless monitoring, but also to secure communications and data protection. Tarabasz and Poddar (2019) proposed the following classification of smart devices (Table no. 1).

Borowski-Beszta and Polasik (2020) consider that these devices have several common characteristics, such as:

- Hands-free use, which allows users to do different tasks at the time;

- Controllable character (the user can control it at any time);

- Relationship with the external environment (the devices are provided with multiple sensors and working modes);

- Provide additional information (providing alerts, reminders, or messages that retain the user's attention); 
- Communicate with each other (they are able to exchange information over an IoT wireless network)

- Works in the background (the user can operate independently; the device does not need his attention)

Table No. 1. Classification of smart devices

\begin{tabular}{|c|c|c|}
\hline Sector & Type & Body area \\
\hline $\begin{array}{l}\text { Consumers } \\
\text { - Health } \\
\text { - Sport and fitness } \\
\text { - Information } \\
\text { - Games and free time } \\
\text { Professional } \\
\text { - Commercial } \\
\text { - Industrial } \\
\text { - Military } \\
\text { - Others }\end{array}$ & $\begin{array}{l}\text { - Smartwatch } \\
\text { - Fitness tape } \\
\text { - Virtual glasses } \\
\text { - Smart Clothes } \\
\text { - Medical devices } \\
\text { - Games }\end{array}$ & $\begin{array}{l}\text { - Head } \\
\text { - Ear } \\
\text { - Eye } \\
\text { - Shoulders } \\
\text { - Elbow } \\
\text { - Wrists } \\
\text { - Feet }\end{array}$ \\
\hline
\end{tabular}

The adoption of smart devices has increased in recent times, driven by both consumer demand and the growing supply proposed by flagship companies such as Apple, Microsoft or Google. However, the adoption of this technology is subject to the same types of factors influencing consumer decisions in general. Following quantitative research conducted in Dubai, Tarabasz and Poddar (2019) identify the following important factors in the adoption of smart devices: safety, product attributes, behavioral motivations, perceived utility and perceived easy use. In the same note and in a similar procedure, based on TAM, Yu-Sheng, Nawata and Huang (2019) examine the adoption of one of the most widespread devices, the fitness band. The authors mention the following factors as the most important: perceived use, expected performance, perceived utility, external network connection, degree of innovation, degree of knowledge of technology, adoption intent, and usage behavior.

\subsection{Theories about Technology Acceptance: TAM and TAM 2}

In order to effectively implement an information system or technology, it is essential to understand the user's consumer behavior and preferences. In recent decades, the focus has been on developing theoretical models that can explain and predict user's acceptance of new technologies. One of the most representative models of acceptance of technology is TAM, which has been extended to TAM 2.

TAM (Figure no. 2), is a component part of the Theory of Reasoned Action (TRA), theory that analyses human behavior. Thus, according to the two dimensions: perceived usefulness and perceived ease of use it can predict the intention of consumer behavior and acceptance of technology (Venkatesh and Davis, 2000). The first dimension refers to the possible level of effortless use of technology, and the perceived ease of use demonstrates the extent to which consumers believe that their use would not require a major effort (Gao and Bai, 2014, Davis, 1989). The Technology Acceptance Model has been used in various studies such as: adopting online shopping (McCloskey, 2003); e-learning and mobile financial services (Lee et al., 2012); internet banking (Al-Ajam and Nor, 2013). 


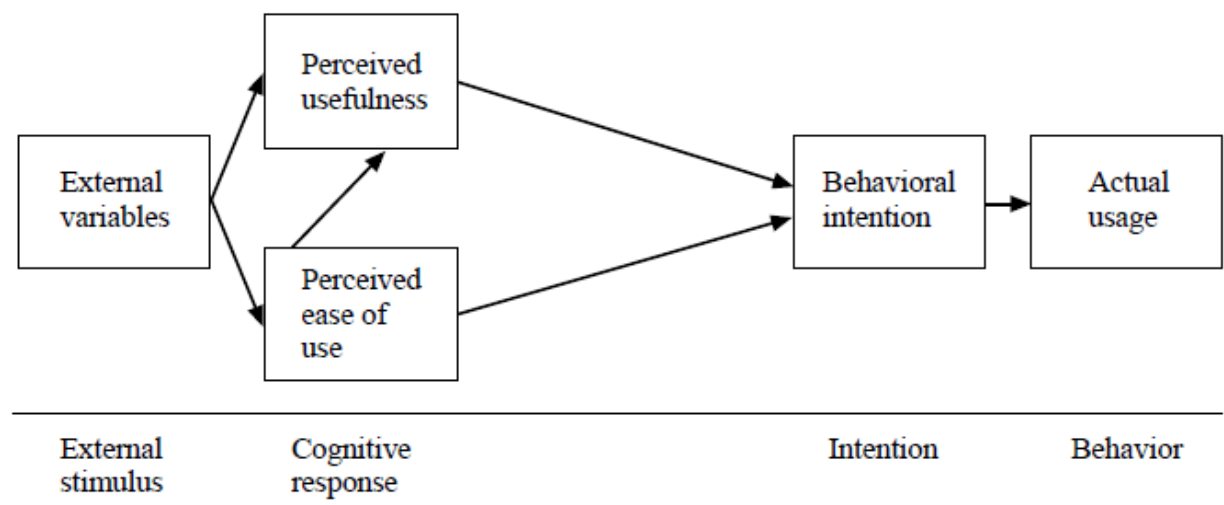

Figure no. 2. Technology acceptance model (TAM)

Source: Davis and Venkatesh, 1996, p. 20

This model was created to predict the use of the IT system in the workplace (Gao and Bai, 2014), but variables can be used to predict consumer behavior to accept IoT technology. Numerous researches have analysed the fact that TAM can predict $40 \%$ of what the behavior and intent of users might be (Venkatesh and Davis, 2000).

Subsequently, the authors Venkatesh and Davis (2000) expanded the original model TAM, based on empirical and theoretical developments by adding additional elements on the process of social influence and cognitive instruments. Thus, TAM 2 (Figure no. 3) includes in the first category the following: image, voluntariness and subjective norm and, in the second category: result demonstrability, output quality, job relevance and perceived ease of use (Venkatesh and Davis, 2000) in order to understand the consumers' ability to accept new technologies.

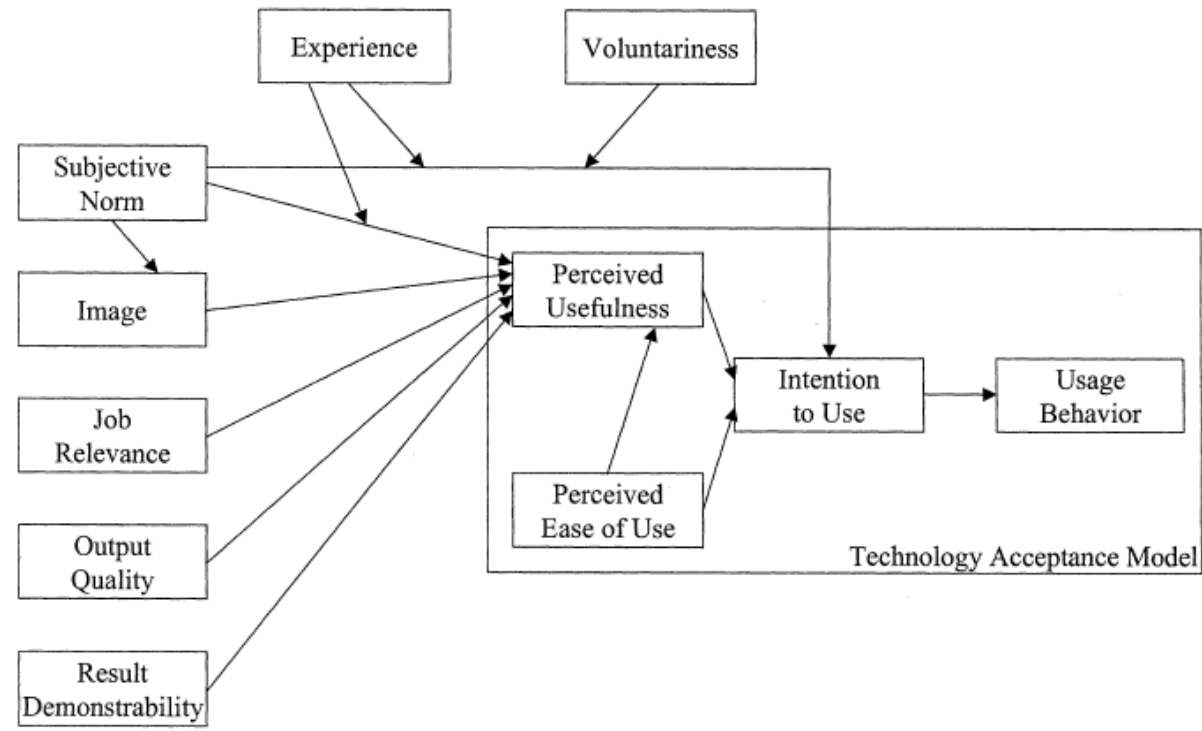

Figure no. 3. TAM Proposal 2

Source: Venkatesh and Davis, 2000, p.188 
Improving the TAM model by introducing those three interconnected social forces (image, voluntariness and the subjective norm) will predict how an individual will react when faced with the situation of rejecting or accepting a new system/technology (Venkatesh and Davis, 2000):

- The image reflects the level by which a consumer uses technology to improve and present their status within a social group (Moore and Benbasat, 1991);

- Voluntariness presents the optional decision of the users on the purchase process;

- The subjective norm investigates the use of technology according to an individual's perception of the opinion of those close to him.

The process of cognitive instruments in the TAM 2 model reflects (Venkatesh and Davis, 2000, p.190):

- Job relevance describes the user's perception of the applicability of the technology within the service;

- Output quality demonstrates the consumer's opinion on the results of the use of innovative technology in its service;

- The perceived ease of use remained the same from the original TAM model, being a direct factor of perceived utility (F. D. Davis, 1989);

- Result demonstrability suggests the concrete result of the use of technology/innovation.

\section{Research model and hypotheses}

This study proposes a new model to examine the underlying factors affecting the attitude towards the use and the intention to use wearable devices. The proposed model is based on the TAM framework, which has been successfully applied in related wearable technology studies (Lunney, Cunningham and Eastin, 2016; Nascimento, Oliveira and Tam, 2018; Jung, Kim and Chiu, 2019). This research model is shown in Figure no. 4.

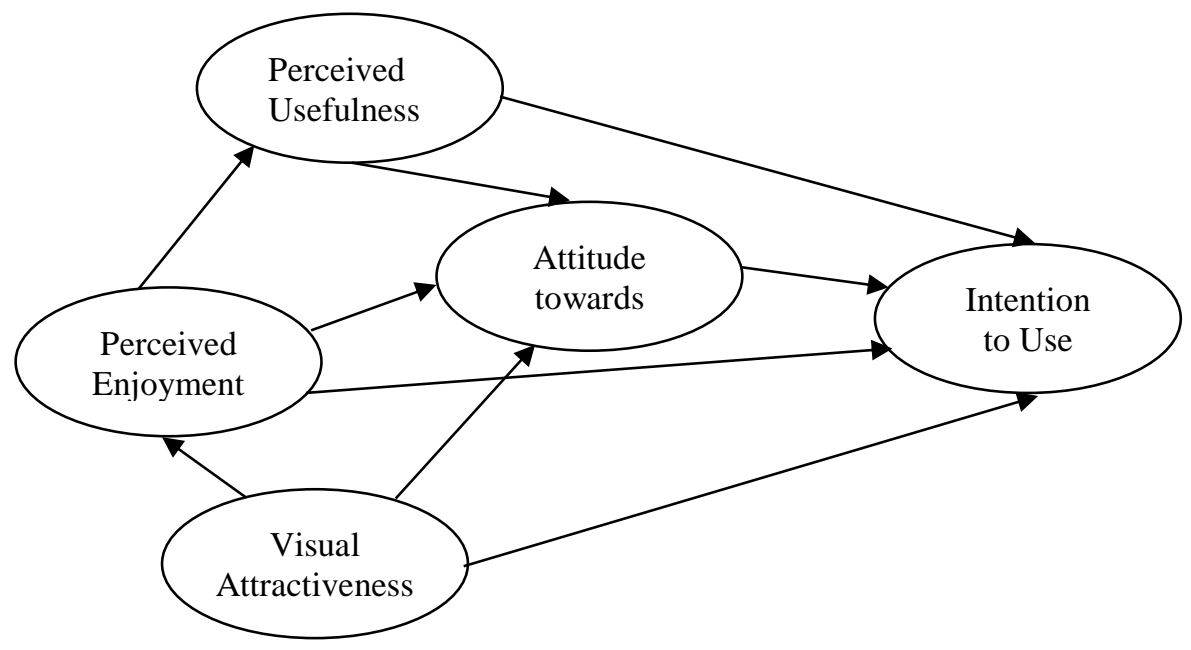

Figure no. 4. The proposed conceptual model 
Davis (1989, p. 320) defines perceived usefulness as "the degree to which a person believes that using a particular system would enhance his or her job performance". Users of wearable devices can improve their life and productivity by monitoring health and different activities, receiving notification about their mail and meetings, accessing information, and communicating with others via Internet. In the context of smart wearable devices, perceived usefulness is employed as a direct determinant of both users' attitude towards the use and intention to use (Choi and Kim, 2016; Park, 2020). This study therefore proposes the following hypothesis:

H1. There will be a positive relationship between the perceived usefulness of wearable devices and the attitude towards using wearable devices.

H2. There will be a positive relationship between the perceived usefulness of wearable devices and the intention to use wearable devices.

According to Ko et al. (2009, p. 264), perceived enjoyment, is defined as "the level to which using a specific technology or service is seen as enjoyable". Perceived enjoyment is an important factor for wearable technology. Previous studies have identified that perceived enjoyment has a significant impact on the attitude toward using the smartwatch $(\mathrm{Wu}, \mathrm{Wu}$ and Chang, 2016). Other studies have examined the relationship between perceived enjoyment and intention to use smart wearable devices (Kim and Shin, 2015). Thus, we hypothesize that:

H3. There will be a positive relationship between the perceived enjoyment of wearable devices and the attitude towards using wearable devices.

H4. There will be a positive relationship between the perceived enjoyment of wearable devices and the intention to use wearable devices.

H5. There will be a positive relationship between the perceived enjoyment of wearable devices and the perceived usefulness of wearable devices.

Wearable technology is complex because it merges the characteristics of electronic devices with those of fashion and clothing. In this regard, Yang et al (2016, p.260) defines visual attractiveness as "an aesthetic product design expressed through shapes, colours, and materials and user interfaces such as device menus and the mobile applications of wearable devices". Jeong et al (2017) found that the perceived aesthetics of wearable devices has a positive effect on the intention of purchasing wearable devices. In addition, visual attractiveness can be a significant factor that influences perceived enjoyment as well as the attitude towards using wearables devices. Therefore, we hypothesize that:

H6. There will be a positive relationship between the visual attractiveness of wearable devices and the attitude towards using wearable devices.

H7. There will be a positive relationship between the visual attractiveness of wearable devices and the intention to use wearable devices.

H8. There will be a positive relationship between the visual attractiveness of wearable devices and the perceived enjoyment of wearable devices.

According to Chuah et al (2016, p. 277), the attitude toward using technology is defined as "a person's overall judgment of using a technology and the technology itself". The main endogenous variable, the intention to use a technology reflects a person's desire to start using 
a technology (Davis, 1989). Regarding wearable devices, previous studies that applied TAM found a positive relationship between the attitude toward use and the intention to adopt these technologies. (Jung, Kim and Choi, 2016). Thus, we also hypothesizes that:

H9. There will be a positive relationship between the attitude toward the use of wearable devices and the intention to use of wearable devices.

\section{Research methodology}

A quantitative research design was adopted for this exploratory study. An online survey was administered to business students at The Bucharest University of Economic Studies, a higher education institution from Romania. The survey began with a brief description and examples of wearable technologies. Students were also informed that participation in the study was entirely voluntary and guarantees anonymity. The first part of the questionnaire included demographic items relating to the participants' age, gender, years of studies and employment status. The second part of the survey consisted of multi-item measures on a seven-point Likert scales (from 1 totally disagree to 7 totally agree) that were adapted in the context of wearable technologies. An overview of the constructs, items and references are presented in Table no. 2.

Table no. 2. Survey items used in this study

\begin{tabular}{|c|c|c|c|}
\hline Construct & Item & Contents & References \\
\hline $\begin{array}{l}\text { Perceived } \\
\text { Usefulness } \\
\text { (PU) }\end{array}$ & $\begin{array}{l}\text { PU1 } \\
\text { PU2 } \\
\text { PU3 } \\
\text { PU4 }\end{array}$ & $\begin{array}{l}\text { I think that smart wearable devices are useful } \\
\text { for my life } \\
\text { Using smart wearable devices increases my } \\
\text { productivity } \\
\text { Using smart wearable devices helps me } \\
\text { conveniently perform many tasks } \\
\text { Wearable devices provide very useful service } \\
\text { and information to me }\end{array}$ & $\begin{array}{l}\text { Davis, } \\
1989 \text {; Park, } \\
2020\end{array}$ \\
\hline $\begin{array}{l}\text { Perceived } \\
\text { Enjoyment } \\
\text { (PE) }\end{array}$ & $\begin{array}{l}\text { PE1 } \\
\text { PE2 } \\
\text { PE3 } \\
\text { PE4 }\end{array}$ & $\begin{array}{l}\text { Using wearable devices is truly fun } \\
\text { I enjoy using smart wearable devices } \\
\text { Using smart wearable devices gives me a lot of } \\
\text { enjoyment } \\
\text { The use of wearable devices makes me feel } \\
\text { good }\end{array}$ & $\begin{array}{l}\text { Yang et al, } \\
\text { 2016; } \\
\text { Park, } 2020\end{array}$ \\
\hline $\begin{array}{l}\text { Visual } \\
\text { Attractiveness } \\
\text { (VA) }\end{array}$ & $\begin{array}{l}\text { VA1 } \\
\text { VA2 } \\
\text { VA3 } \\
\text { VA4 }\end{array}$ & $\begin{array}{l}\text { The design of wearable devices is attractive to } \\
\text { me } \\
\text { The user interface of wearable devices (i.e., } \\
\text { colours, boxes, menus, etc.) is attractive } \\
\text { The design of wearable devices is cool to me } \\
\text { The overall look and feel of wearable devices } \\
\text { is visually appealing }\end{array}$ & $\begin{array}{l}\text { Jeong et al, } \\
2017 \text {; } \\
\text { Yang et al, } \\
2016 \text {; }\end{array}$ \\
\hline $\begin{array}{l}\text { Attitude } \\
\text { Towards Use } \\
\text { (ATU) }\end{array}$ & $\begin{array}{l}\text { ATU1 } \\
\text { ATU2 } \\
\text { ATU3 } \\
\text { ATU4 }\end{array}$ & $\begin{array}{l}\text { I feel positive regarding the utilization of } \\
\text { wearable devices } \\
\text { In general, I admire the utilization of wearable } \\
\text { devices } \\
\text { I think it is a trend to use wearable devices } \\
\text { Overall, I like using the wearable devices }\end{array}$ & $\begin{array}{l}\text { Davis et al, } \\
1989\end{array}$ \\
\hline
\end{tabular}




\begin{tabular}{|l|l|l|l|}
\hline Construct & Item & Contents & References \\
\hline $\begin{array}{l}\text { Intention to } \\
\text { Use }\end{array}$ & IU1 & $\begin{array}{l}\text { I intend to use wearable devices in the next } \\
\text { months }\end{array}$ & $\begin{array}{l}\text { Li et al. } \\
\text { (1989) }\end{array}$ \\
\hline IU2 & $\begin{array}{l}\text { I will make use of wearable devices regularly in } \\
\text { the forthcoming time }\end{array}$ & $\begin{array}{l}\text { I will give out my recommendation to others to } \\
\text { use wearable devices } \\
\text { I will use more wearable devices in the future. }\end{array}$ & \\
\hline
\end{tabular}

The questionnaire was hosted on a free platform and the invitation to participate at the survey was sent to the students who are enrolled in bachelor and master programs of Faculty of Business and Tourism during the first semester of the school year 2020-2021. Data was collected over a two weeks period in November 2020 and was imported into the SmartPLS 3.3.2 software package for further analysis.

\section{Results and discussion.}

This section presents the results of this study. The first part presents the descriptive statistics regarding the characteristics of respondents. The second part evaluates the reliability and validity of the proposed model. The third part analyse the relationship between exogenous and endogenous variables within the model and tests the hypothesis.

\subsection{Descriptive statistics}

The total number of respondents of the survey was one hundred ninety-two. The participants ranged in age from 19 to 36 years old (Mean=21.9, Std. Deviation=2.022). The rest of the information about the participants is presented in Table no 3.

Table no 3. Characteristics of the respondents.

\begin{tabular}{|l|c|c|}
\hline Characteristics & Respondents $(\mathbf{n}=\mathbf{1 9 2})$ & Percent \\
\hline Gender & & \\
Male & 52 & 27.0 \\
Female & 140 & 73.0 \\
\hline Scholar status & & \\
Bachelor student & 98 & 51.0 \\
Master student & 94 & 49.0 \\
\hline Employment status & & \\
Working full time & 71 & 37.0 \\
Working part time & 28 & 14.6 \\
Unemployed & 93 & 48.4 \\
\hline
\end{tabular}

\subsection{Reliability and validity}

We used Partial Least Squares (PLS) analysis to measure the reliability and validity of the proposed model. Cronbach's alpha and Composite reliability was used to test construct internal consistency. Cronbach's Alpha and the Composite Reliability values between 0.60 and 0.70 are considered acceptable in exploratory research and values between 0.70 and 0.90 range from satisfactory to good (Hair et al., 2019). Convergent validity of the constructs was measured by Average Variance Extracted (AVE). The acceptable threshold for Average 
Variance Extracted is 0.50 (Hair et al. 2014). Table no 4 shows that Cronbach's alpha, Composite reliability and Average Variance

Table no 4. Constructs Reliability and Validity

\begin{tabular}{|l|l|l|l|}
\hline & $\begin{array}{l}\text { Cronbach's } \\
\text { Alpha }>\mathbf{0 . 7}\end{array}$ & $\begin{array}{l}\text { Composite } \\
\text { Reliability }>\mathbf{0 . 7}\end{array}$ & $\begin{array}{l}\text { Average Variance } \\
\text { Extracted (AVE) }>\mathbf{0 . 5}\end{array}$ \\
\hline Attitude Towards Use & 0.829 & 0.885 & 0.662 \\
\hline Intention to Use & 0.917 & 0.942 & 0.802 \\
\hline Perceived Enjoyment & 0.885 & 0.921 & 0.745 \\
\hline Perceived Usefulness & 0.841 & 0.894 & 0.678 \\
\hline Visual Attractiveness & 0.912 & 0.938 & 0.792 \\
\hline
\end{tabular}

Extracted values for each of the five constructs of the proposed model exceeds the minimum thresholds indicating high convergent reliability and validity.

To evaluate the discriminant validity, the square root of the Average Variance Extracted of each construct have to be compared with its inter-construct correlation. The square root of each construct's AVE should be higher than the correlation between the constructs in order to satisfy discriminant validity requirement (Fornell and Larcker, 1981). Table no. 5 shows that all square roots of the AVEs on the diagonal are higher than the correlations between constructs and indicates adequate discriminant validity of the measurements.

Table no. 5. Discriminant Validity Results

\begin{tabular}{|l|l|l|l|l|l|}
\hline & $\begin{array}{l}\text { Attitude } \\
\text { Towards Use }\end{array}$ & $\begin{array}{l}\text { Intention } \\
\text { to Use }\end{array}$ & $\begin{array}{l}\text { Perceived } \\
\text { Enjoyment }\end{array}$ & $\begin{array}{l}\text { Perceived } \\
\text { Usefulness }\end{array}$ & $\begin{array}{l}\text { Visual } \\
\text { Attractiveness }\end{array}$ \\
\hline $\begin{array}{l}\text { Attitude } \\
\text { Towards Use }\end{array}$ & $\mathbf{0 . 8 1 4}$ & & & & \\
\hline $\begin{array}{l}\text { Intention to } \\
\text { Use }\end{array}$ & 0.683 & $\mathbf{0 . 8 9 6}$ & & & \\
\hline $\begin{array}{l}\text { Perceived } \\
\text { Enjoyment }\end{array}$ & 0.704 & 0.642 & $\mathbf{0 . 8 6 3}$ & & \\
\hline $\begin{array}{l}\text { Perceived } \\
\text { Usefulness }\end{array}$ & 0.632 & 0.702 & 0.649 & $\mathbf{0 . 8 2 3}$ & \\
\hline $\begin{array}{l}\text { Visual } \\
\text { Attractiveness }\end{array}$ & 0.527 & 0.342 & 0.447 & 0.383 & $\mathbf{0 . 8 9}$ \\
\hline
\end{tabular}

In addition, an inspection of the overall model reveals a satisfactory model fit, as shown by the Standardized Root Mean Square Residual (SRMR=0.072). The SRMR is the square root of the sum of the squared differences between the model-implied and the empirical correlation matrix (Henseler, Hubona, and Pauline, 2016). A value of 0.08 as proposed by $\mathrm{Hu}$ and Bentler (1999) indicates an acceptable fit for PLS path models.

\subsection{Structural model}

Structural equation modelling (SEM) has become widely applied in many social science researches to analyse the cause-effect relations between latent variables. Among variancebased SEM methods, Partial Least Squares (PLS) path modelling approach is considered as a "silver bullet" and can be applied to a wider range of situations (Hair, Ringle and Sarstedt, 2011). 
The structural proposed model was analysed with SmartPLS, a software with graphical user interface for conducting PLS-SEM analyses. A complete bootstrap procedure has been performed with 5000 bootstrap subsamples to measure the significance of the hypothesized relationships among the variables. The path coefficients of the structural model and R-square values for endogenous latent variables are presented in Figure no. 5.

The paths coefficients are considered statistically significant if the t-statistics give a value above 1.96 at the 0.05 significance level. According to Cohen (2013), values above 0.35, 0.15 , and 0.02 can be regarded as strong, moderate, and weak.

The results showed first that perceived usefulness was positively related to both attitude towards use $(\beta=0.264, \mathrm{t}=4.134, \mathrm{p}<.001)$ and intention to use $(\beta=0.399, \mathrm{t}=6.4333, \mathrm{p}<.001)$, thus $\mathrm{H} 1$ and $\mathrm{H} 2$ were supported. Second, perceived enjoyment was a significant predictor of attitude towards use $(\beta=0.428, \mathrm{t}=6.84, \mathrm{p}<.001)$, intention to use $(\beta=0.168, \mathrm{t}=2.277, \mathrm{p}<.0023)$ and perceived usefulness $(\beta=0.649, \mathrm{t}=15.149, \mathrm{p}<.001)$. Therefore, hypothesis H3, H4 and H5 were supported.

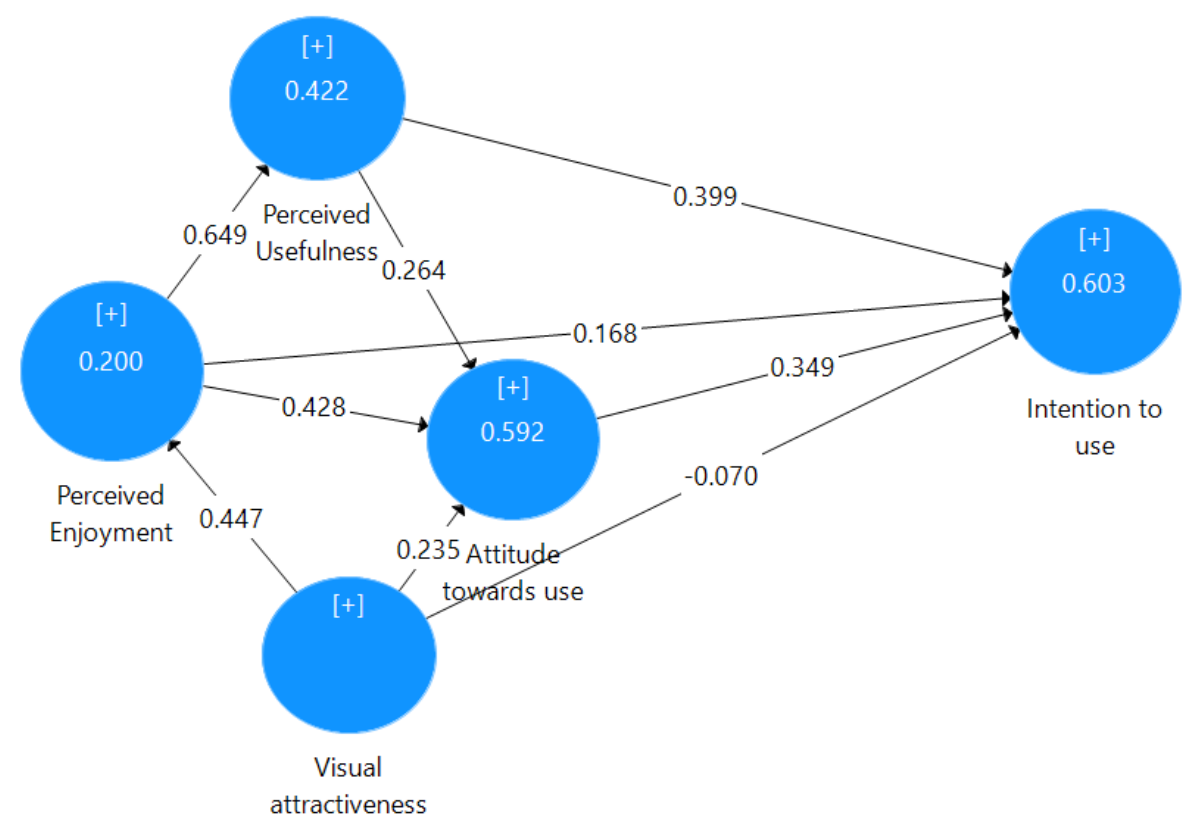

Figure no. 5. Relationship Model with Path Coefficients and R-square

Third, visual attractiveness positively influenced attitude towards use $(\beta=0.235, t=3.613$, $\mathrm{p}<.001)$ and perceived enjoyment $(\beta=0.447, \mathrm{t}=6.076, \mathrm{p}<.001)$, thus providing support for H6 and H8. However, visual attractiveness appeared to have no significant influence on intention to use, thus $\mathrm{H} 7$ was not supported. Finally, attitude towards use had a positive relationship with intention to use $(\beta=0.349, \mathrm{t}=4.932, \mathrm{p}<.001)$, thus H9 was supported. The results of the hypothesis testing are summarized in Table no. 6. 
Table no. 6. Summary of hypothesis.

\begin{tabular}{|l|l|l|l|l|c|}
\hline \multicolumn{2}{|c|}{ Hypothesis } & Coefficients $\boldsymbol{\beta}$ & t Values & p Values & Result \\
\hline H1 & PU $\rightarrow$ ATU & 0.264 & 4.134 & 0.000 & Supported \\
\hline H2 & PU $\rightarrow$ IU & 0.399 & 6.433 & 0.000 & Supported \\
\hline H3 & PE $\rightarrow$ ATU & 0.428 & 6.84 & 0.000 & Supported \\
\hline H4 & PE $\rightarrow$ IU & 0.168 & 2.277 & 0.023 & Supported \\
\hline H5 & PE $\rightarrow$ PU & 0.649 & 15.149 & 0.000 & Supported \\
\hline H6 & VA $\rightarrow$ ATU & 0.235 & 3.613 & 0.000 & Supported \\
\hline H7 & VA $\rightarrow$ IU & -0.07 & 1.414 & 0.158 & Not Supported \\
\hline H8 & VA $\rightarrow$ PE & 0.447 & 6.076 & 0.000 & Supported \\
\hline H9 & ATU $\rightarrow$ IU & 0.349 & 4.932 & 0.000 & Supported \\
\hline \multicolumn{7}{|l|}{ *significant at $p<0.05, * * *$ significant at p < 0.001.} &
\end{tabular}

R-square, also called the coefficient of determination, measures the variance in the endogenous variable that is explained by the observed exogenous variables. R-square is the overall effect size measure for the structural model and indicate that $59.2 \%$ of the variance in the variable Attitude towards Use and $60.3 \%$ in the variable Intention to Use is explained by the model. According to Chin (1998), the values of R-square are 0.67 for substantial, 0.33 for moderate and 0.19 for weak path models. The R-square values of this model can be considered as moderate strength or effect.

\section{Conclusions}

The study is part of the wider context of the explosion of IoT technology in all fields, both in the professional and the personal sphere and is comprised of// comprises an exploratory study focused on understanding the elements that impact Romanian students' attitude towards use and intention to use wearable devices. The research is part of the wider context of the explosion of IoT technology in all fields, both in the professional and the personal sphere. To accomplish this, the paper proposes a structural model based on the Technology Acceptance Model (TAM) to which were added other two variables: Perceived Enjoyment and Visual Attractiveness. Wearable devices that are perceived as useful, enjoyable and attractive are the most likely to be adopted by young people and are more likely to gain a larger market share. To test the proposed conceptual model, first a quantitative research was conducted and online survey responses from Romanian students were collected. Second, Partial Least Squares (PLS) analysis was used to measure the reliability and validity of the proposed model. Subsequently, PLS-SEM was used to analyse the relationship between variables and test the hypothesis. The results of the study showed that perceived usefulness, perceived enjoyment and visual attractiveness positively influenced the attitude towards use and intention to use wearable devices with one exception. Visual attractiveness had no significant influence on the intention to use although it positively influenced attitude towards using wearable devices. These results extend the literature regarding the adoption of wearable devices technology among young users and provide useful information to the industry.

The limits of this study are primarily the size and structure of the sample. Young people, especially those with higher education, have a natural predisposition to the use of new technologies, being very receptive and curious. On the other hand, they are also the main 
recipients of these technologies, with the major producers in the field having active campaigns to promote young people.

Possible future research directions include testing the adoption of these devices in the professional or commercial environment. We believe that there is also significant development potential here, by integrating these devices into complex IoT systems (e.g., production management, monitoring in the logistics and distribution area etc.). In this context, the economic impact will need to be studied in detail in order to highlight the contributions to the area of profitability growth brought by wearable devices.

\section{References}

Al-Ajam, A.S. and Nor, K.M., 2013. Internet banking adoption: integrating technology acceptance model and trust. European Journal of Business and Management, 5(3), pp.207-215.

Borowski-Beszta, M. and Polasik, M., 2020. Wearable devices: New quality in sports and finance. Journal of Physical Education and Sport, 20, pp.1077-1084.

Chin, W. W., 1998. The partial least squares approach for structural equation modeling. In G.A. Marcoulides ed. 1998. Methodology for business and management. Modern methods for business research. NJ: Lawrence Erlbaum Associates Publishers, pp. 295-336.

Choi, J. and Kim, S., 2016. Is the smartwatch an IT product or a fashion product? A study on factors affecting the intention to use smartwatches. Computers in Human Behavior, 63 , pp.777-786.

Chuah, S., Rauschnabel, P., Krey, N., Nguyen, B., Ramayah, T. and Lade, S., 2016. Wearable technologies: The role of usefulness and visibility in smartwatch adoption. Computers in Human Behavior, 65, pp.276-284.

Cohen, J., 2013. Statistical Power Analysis for The Behavioral Sciences. Hoboken: Taylor and Francis.

Davis, F.D. and Venkatesh, V., 1996. A critical assessment of potential measurement biases in the technology acceptance model: three experiments. International Journal of HumanComputer Studies, 45(1), pp.19-45.

Davis, F.D., 1989. Perceived Usefulness, Perceived Ease of Use, and User Acceptance in Information Technology, MIS Quarterly, 13(3), pp.319-340.

Davis, F.D., Bagozzi, R.P., Warshaw, P.R., 1989. User acceptance of computer technology: a comparison of two theoretical models. Management Science, 35(8), pp. 982-1003.

Fornell, C. and Larcker, D.F., 1981. Evaluating Structural Equation Models with Unobservable Variables and Measurement Error. Journal of Marketing Research, 18, pp. 39-50.

Gao, L. and Bai, X., 2014. A unified perspective on the factors influencing consumer acceptance of internet of things technology. Asia Pacific Journal of Marketing and Logistics, 26(2), pp.211-231.

Hair, J., Black, W., Babin, B. and Anderson, R., 2014. Multivariate data analysis. $7^{\text {th }}$ ed. Upper Saddle River: Pearson Education.

Hair, J.F., Ringle, C.M., and Sarstedt, M., 2011. PLS-SEM: indeed a silver bullet. Journal of Marketing Theory and Practice, 19(2), pp. 139-151. 
Hair, J.F., Risher, J.J., Sarstedt, M., and Ringle, C. M., 2019. When to use and how to report the results of PLS-SEM. European Business Review, 31(1), pp. 2-24.

Henseler, J., Hubona, G., and Pauline, A.R., 2016. Using PLS path modeling in new technology research: Updated guidelines. Industrial Management and Data Systems, 116(1), pp.2-20.

Hu, L.T. and Bentler, P.M., 1999. Cutoff criteria for fit indexes in covariance structure analysis: conventional criteria versus new alternatives, Structural Equation Modeling, 6(1), pp. 1-55.

Ibarra-Esquer, J., González-Navarro, F., Flores-Rios, B., Burtseva, L. and Astorga-Vargas, M., 2017. Tracking the Evolution of the Internet of Things Concept Across Different Application Domains. Sensors, 17(6), p.1379.

ITU, 2012. Recommendation ITU-T Y.2060: Overview of the Internet of things. [online] Available at: <https://www.itu.int/rec/T-REC-Y.2060-201206-I/en> [Accessed 16 December 2020].

Jeong, S., Kim, S., Park, J. and Choi, B., 2017. Domain-specific innovativeness and new product adoption: A case of wearable devices. Telematics and Informatics, 34(5), pp.399-412.

Jin, Y. \& Ji, S. 2018. Mapping hotspots and emerging trends of business model innovation under networking in Internet of Things. EURASIP Journal on Wireless Communications and Networking, 2018(1), pp. 1-12.

Jung, Y., Kim, S. and Choi, B., 2016. Consumer valuation of the wearables: The case of smartwatches. Computers in Human Behavior, 63, pp.899-905.

Khakurel J., Pöysä S., Porras J., 2017. The Use of Wearable Devices in the Workplace - A Systematic Literature Review. In: O. Gaggi, P. Manzoni, C. Palazzi, A. Bujari and J. Marquez-Barja (eds.). Smart Objects and Technologies for Social Good. GOODTECHS 2016. Lecture Notes of the Institute for Computer Sciences, Social Informatics and Telecommunications Engineering, vol 195. Springer, Cham.

Kim, K.J. and Shin, D.H., 2015. An acceptance model for smart watches: Implications for the adoption of future wearable technology. Internet Research, 25(4), pp. 527-541.

Kim, T. and Chiu, W., 2019. Consumer acceptance of sports wearable technology: the role of technology readiness. International Journal of Sports Marketing and Sponsorship, 20(1), pp.109-126.

Klein, A., Pacheco, F.B. and Righi, R.d.R., 2017. Internet of things-based products/ services: process and challenges on developing the business models. Journal of Information Systems and Technology Management: JISTEM, 14(3), pp. 439-461.

Ko, E., Sung, H. and Yun, H., 2009. Comparative Analysis of Purchase Intentions Toward Smart Clothing Between Korean and U.S. Consumers. Clothing and Textiles Research Journal, 27(4), pp.259-273.

Lee, Y.K., Park, J.H., Chung, N. and Blakeney, A., 2012. A unified perspective on the factors influencing usage intention toward mobile financial services. Journal of Business Research, 65(11), pp. 1590-1599.

Li, J., Ma, Q., Chan, A. and Man, S., 2019. Health monitoring through wearable technologies for older adults: Smart wearables acceptance model. Applied Ergonomics, 75, pp.162-169. 
Lunney, A., Cunningham, N. and Eastin, M., 2016. Wearable fitness technology: A structural investigation into acceptance and perceived fitness outcomes. Computers in Human Behavior, 65, pp.114-120.

McCloskey, D., 2003. Evaluating electronic commerce acceptance with the technology acceptance model. Journal of Computer Information Systems, 44(2), pp. 49-57.

Moore, G.C., Benbasat, I., 1991. Development of an instrument to measure the perceptions of adopting an information technology innovation. Information Systems Research, 2(3), pp.192-222.

Murray, A., Papa, A., Cuozzo, B. and Russo, G. 2016. Evaluating the innovation of the Internet of Things. Business Process Management Journal, 22(2), pp. 341-356.

Nascimento, B., Oliveira, T. and Tam, C., 2018. Wearable technology: What explains continuance intention in smartwatches?. Journal of Retailing and Consumer Services, 43, pp.157-169.

Nicolescu, R., Huth, M., Radanliev, P. and De Roure, D. 2018. Mapping the values of IoT. Journal of Information Technology, 33(4), pp. 345-360.

Onete, C.B., Pleșea, D.A. and Albăstroiu, I., 2017. Opportunities and Challenges of the Internet of Things related to Consumer. In: R. Pamfilie, V. Dinu, D.A. Pleșea and C. Vasiliu (eds.), Proceedings of 2017 BASIQ International Conference: New Trends in Sustainable Business and Consumption. Graz, Austria, 31 May - 3 June 2017. Bucharest: ASE Publishing House. pp. 478-486.

Park, E., 2020. User acceptance of smart wearable devices: An expectation-confirmation model approach. Telematics and Informatics, 47, pp. 101318.

Russo, G., Marsigalia, B., Evangelista, F., Palmaccio, M. and Maggioni, M. 2015. Exploring regulations and scope of the Internet of Things in contemporary companies: a first literature analysis. Journal of Innovation and Entrepreneurship, 4(1), pp. 1-13.

Tarabasz, A. and Poddar, G. 2019. Factors influencing adoption of wearable devices in Dubai. Journal of Economics \& Management, 36, pp. 123-143.

Tohanean, D., Toma, S.G. and Dumitru, I., 2018. Organizational Performance and Digitalization in Industry 4.0. Journal of Emerging Trends in Marketing and Management, 1(1), pp.282-288.

Uden, L. and $\mathrm{Wu}, \mathrm{H} ., 2017$. How the Internet of Things can help knowledge management: a case study from the automotive domain. Journal of Knowledge Management, 21(1), pp.57-70.

Venkatesh, V. and Davis, F., 2000. A Theoretical Extension of the Technology Acceptance Model: Four Longitudinal Field Studies. Management Science, 46(2), pp.186-204.

Westerlund, M., Leminen, S. and Rajahonka, M., 2014. Designing Business Models for the Internet of Things. Technology Innovation Management Review, 4(7), pp. 5-14.

Wu, L.H., Wu, L.C. and Chang, S.C., 2016. Exploring consumers' intention to accept smartwatch. Computers in Human Behavior, 64, pp.383-392.

Yang, H., Yu, J., Zo, H. and Choi, M., 2016. User acceptance of wearable devices: An extended perspective of perceived value, Telematics and Informatics, 33(2), pp.256-269.

Yu-Sheng, K., Nawata, K. and Huang, C., 2019. An Exploration and Confirmation of the Factors Influencing Adoption of IoT-Based Wearable Fitness Trackers. International Journal of Environmental Research and Public Health, 16(18), p.3227. 